\title{
Enculturation of Kethoprak Babad Tulungagung Through Educational Strategy in Facing Cultural Globalization
}

\author{
Arief Sudrajat ${ }^{1}$ Zulfana D. Ariska ${ }^{1, *}$ Ayu Febriani ${ }^{2}$ Fakhrial E. Widodo ${ }^{3}$ \\ 1,2,3 Universitas Negeri Surabaya, East Java, Indonesia \\ Corresponding author.Email: zulfanadwia@gmail.com
}

\begin{abstract}
Kethoprak Babad Tulungagung is a regional art owned by Tulungagung Regency. However, the onslaught of cultural globalization has made the arts degraded. The decline in the existence of the Kethoprak Babad Tulungagung in the younger generation impacts their ignorance of the moral values contained. A qualitative method was employed in this study. Through observation, in-depth interviews, and a literature study, the data collection was carried out. The findings indicated that Kethoprak Babad Tulungagung has moral values that have the potential to educate the younger generation back to their ancestral traits, namely the attitude of njawani (Javanese behavior or manners), noble-minded, etiquette, loyalty, and commitment. Moral values are enculturated through two approaches: the language approach and the socialization approach. The language approach is carried out through slogans in the dialogue performances, while the socialization approach is carried out by incorporating values in the storyline. In addition, supporting actions taken are optimizing social media, updating performances, and collaborating with other kethoprak groups. Thus, the enculturation of Kethoprak Babad Tulungagung is the appropriate educational strategy in preparing the younger generation of Tulungagung to face cultural globalization.
\end{abstract}

Keywords: Babad Tulungagung, Cultural Globalization, Enculturation, Kethoprak.

\section{INTRODUCTION}

Culture is the identity of a region [1]. In this case, culture can include language, social organization, or the arts. The culture that is spread in various parts of Indonesia carries its own meaning in its emergence. The meaning brought can contain wisdom, good value and guidance, which is embedded and followed by the whole society [2]. Tulungagung Regency is one of the areas that has a culture as its regional identity, namely the art of kethoprak. The traditional theatrical art of kethoprak presents folklore stories that have become a favorite spectacle in Tulungagung since 1950-1990. At that time, there was a story that attracted the society, namely the story of Babad Tulungagung.

Babad Tulungagung is a folktale that has been inherited from generation to generation by the ancestors of the Tulungagung society. This folktale is closely related to the pattern of social life, interaction, and religion in Tulungagung. According to Latuberu and Mustika [3], an ability and skill related to local guidance will be obtained from generation to generation in their group. In such a case, the society of Tulungagung Regency get them through the art of Babad Tulungagung. This is also inseparable from the fact that the process of learning to behave in society is an internalization, socialization, and enculturation of a normalized cultural value [4]. In enculturation, the thoughts and attitudes of individuals adjust the system of norms, customs, and regulations that exist in the culture of society [5].

The Tulungagung society's belief towards the moral values of Kethoprak Babad Tulungagung causes the art to become one of the norms of behavior. However, along with the times, an enculturation process of individuals or socio-cultural groups will continue to increase and even change [6]. This reality completely occurs in the phenomenon of the regional culture delegitimization by the lack of knowledge of the younger generation in Tulungagung Regency when compared to the western culture that they follow [7]. In addition, quantity data from the Culture and Tourism 
Office of Tulungagung Regency indicated that during 2019-2020, the percentage of kethoprak arts was only $4 \%$ of the total registered arts (only 3 groups of kethoprak out of 67 registered arts). This situation denotes that the existence of Kethoprak Babad Tulungagung has been delegitimized by the cultural globalization [8].

This problem has encouraged kethoprak activists to find solutions that can maintain the existence of the Kethoprak Babad Tulungagung art. In fact, when the Ki Siswondho Hardjosoewito Association was still victorious, they were able to perform more than 210 plays and succeeded in spreading moral values through the arts. If the Ketoprak Babad Tulungagung art is delegitimized due to globalization, it is feared that the younger generation of Tulungagung will not be able to grasp and preserve the moral values that exist in society. Based on the description of the problems, this study seeks to (1) reveal the moral values of Kethoprak Babad Tulungagung which were enculturated by the previous Tulungagung society; (2) elaborate the solution steps taken by the Tulungagung kethoprak activists so that the society can (especially the younger generation) reenculturate the moral values of the Babad Kethoprak Tulungagung art in facing the cultural globalization.

\section{METHODS}

In this study, the qualitative method was utilized to obtain comprehensive data according to the phenomena that occurred. Informants were selected by using purposive sampling method. To collect data, two methods were used, namely interviews and observations through the key informants. Meanwhile, the supporting data is obtained by conducting literature study of related documents and journals. The data analysis technique used in this study is the interactive model of Miles and Huberman [9]. The selected data from kethoprak art activists, related governments, and surrounding community are displayed first to be processed and verified. Besides, triangulation is used for the data validity so that definite conclusions are obtained [10].

\section{RESULTS AND DISCUSSION}

\subsection{The History of the Development of Kethoprak in Tulungagung}

Kethoprak is a traditional theatrical performance originating from Java. Kethoprak was created by the late Raden Mas Tumenggung Wreksodiningrat in Surakarta in the 1908s. Kethoprak uses traditional percussion instruments, namely small drums, mortar, flute, and tambourine [11]. The dialogue is in the form of tembang (Javanese traditional songs) and is combined with everyday language [12]. According to Koetjaraningrat (1984), kethoprak comes from the word "kethok" which means marker and "prak" which is illustrated as the music.
Tulungagung Regency has a popular kethoprak group, namely Kethoprak Siswo Budoyo. According to Sunardi, as the brother of the Kethoprak Siswo Budoyo founder, this kethoprak was founded on the initiative of Mr. Siswondo Hardjosuwito on June 19, 1958 in Kiping Village, Gondang District, Tulungagung Regency. Kethoprak Siswo Budoyo originates from two words, namely siswo and budoyo which means student or ascetic who subserves Javanese culture [13]. The name above was chosen with the aim that the Siswo Budoyo association can explore, maintain, inspire, and preserve the nation's traditional culture through public entertainment.

Initially, Kethoprak Siswo Budoyo had inter-district performances in Tulungagung. However, due to the high public interest, Kethoprak Siswo Budoyo continued to grow and perform in surrounding cities such as Blitar, Trenggalek, Nganjuk, Madiun to East Java Province. Siswo Budoyo's performance was amazing since it could display the atmosphere realistically. Kethoprak Siswo Budoyo is a type of coastal kethoprak, which is a combination of Kethoprak Mataram (Yogyakarta) with Kethoprak East Java. The coastal kethoprak does not use tembang (Javanese traditional songs) in the overall appearance, tembang is only sung when the role of the king with his vice-regent appears [11]. The kethoprak play that is extremely popular in Tulungagung society is the Babad Tulungagung story. That story has become an icon since it is believed to be a legend from the history of Tulungagung [14]. For example, the story of the Regent of Kalang whose name was used as the name of the village, namely Kalangbret and the story of the Regent of Bethak whose name was used as the name of Bethak Village, and others.

\subsection{Potential Values of Kethoprak Babad Tulungagung to be Enculturated as an Educational Strategy to Face of Cultural Globalization}

The moral value of Kethoprak Babad Tulungagung as an educational strategy came from a statement by one of the activist of Kethoprak Babad Tulungagung, Bambang Widjanarko. Kethoprak likened to a nonformal educational institution as an addition of a school as a formal institution. Culture has the function of being a social arena that can also determine certain successes of humans [15]. The habit of deepening the role will familiarize students to enculturate the moral values of the arts in their daily lives. If moral education is only enculturated in academic learning, namely Javanese language and religion, then formal educational institutions are not critical. Structurally, schools will not be able to undermine the existing system because there are institutionalized rulers and have the authority to dominate the curriculum arena [16]. This gap is only a barrier for students who have interests and talents to 
Table 1. The Revitalization of Kethoprak Babad Tulungagung

\begin{tabular}{|c|c|}
\hline & Moral Value \\
\hline \multirow[t]{3}{*}{ Kethoprak [13] } & $\begin{array}{l}\text { Njawani attitude includes Javanese, ethics, culture and value or morality which has been } \\
\text { preserved in Javanese society. }\end{array}$ \\
\hline & $\begin{array}{l}\text { Adiluhung character is oriented to the principal (virtue) actions based on culture, detail and } \\
\text { right way of thinking, creativity, confidence, and spirit to master all the skills and } \\
\text { potentiality. }\end{array}$ \\
\hline & $\begin{array}{l}\text { Unggah-ungguh attitude with pitutur luhur guidance is two words contain meaning. } \\
\text { Unggah is the Javanese society tendency to respect others based on the status or the social } \\
\text { level of the people, while ungguh is the way to behave and act in the right situation by } \\
\text { considering the appropriateness aspect. }\end{array}$ \\
\hline \multirow[t]{2}{*}{$\begin{array}{l}\text { Babad } \\
\text { Tulungagung [14] }\end{array}$} & $\begin{array}{l}\text { The loyalty attitude of Roro Kembang Sore. She hold her love to Lembu Peteng by not } \\
\text { getting married for the rest of her life even though she had been proposed by Adipati } \\
\text { Kalang. }\end{array}$ \\
\hline & $\begin{array}{l}\text { The commitment shown by Roro Kembang Sore and Lembu Peteng in making decision so } \\
\text { that the goals can be achieved. Roro Kembang Sore had powerful love to Lembu Peteng, } \\
\text { but they could not be together because their parents did not approve their relationship. } \\
\text { The commitment to stay in their choice can be used as a reflection by young generation to } \\
\text { have a commitment and stay on their choices. When they get their commitment, they will } \\
\text { achieve their goals. }\end{array}$ \\
\hline
\end{tabular}

The reality, adults, especially the younger generation, have different habits in responding to cultural developments [17]. The artist crisis occurs because the younger generation of Tulungagung is more interested in and following foreign cultural trends such as the Korean Wave in their lifestyle [18]. Cultural development will also encourage social capital to be different according to the tastes of the younger generation in responding to the decline in the existence of moral values in Kethoprak Babad Tulungagung. The younger generation interested and talented in the arts will be better prepared to enculturate the moral values of their local arts. On the other hand, the main idea contained in moral values is not only to be preached. It must be made a community of cultural heritage sustainably. So, the collaboration among schools, art activists, and the young generation can regenerate Tulungagung youth to maintain the existence of their regional arts according to the times. The cultured spirit that is instilled through character education based on moral values from the normed arts, as well as the ability of youth to access technology, can help Kethoprak activists be able to adapt to the trend of cultural development. The Revitalization of Kethoprak Babad Tulungagung is shown in Table 1.

\subsection{The steps taken by Kethoprak Tulungagung activists in re-enculturating the moral values of art in Kethoprak Babad Tulungagung}




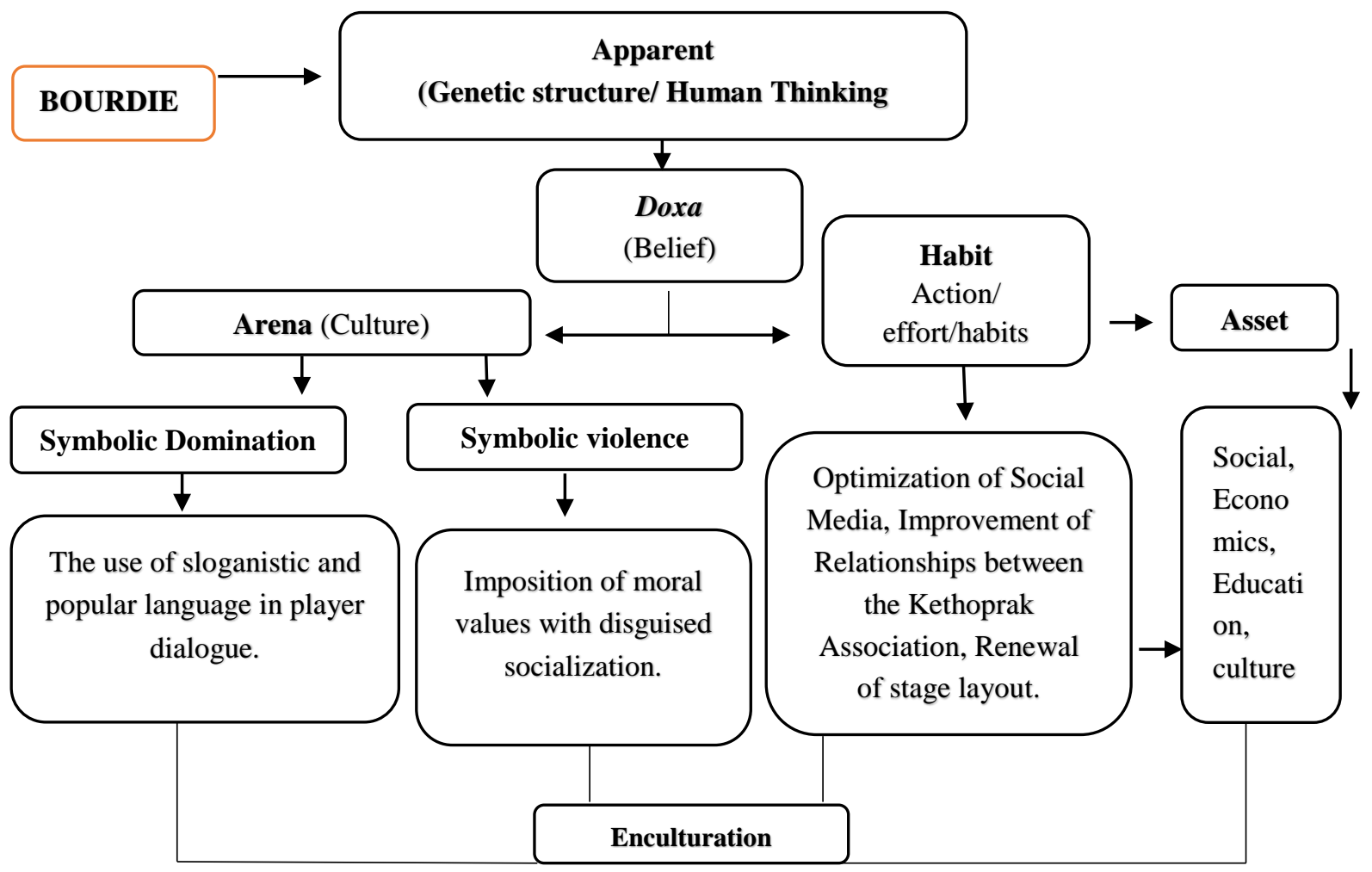

Figure 1 Concept Mechanism of Stock Theory [19].

The enculturation steps pursued are the unity of the social, economic, cultural, and educational capital owned by the Kethoprak group of Tulungagung Regency. Therefore, the Kethoprak group is an agent who has a dialectical relationship with the social structure/system that develops in society. Bourdieu conceptualizes this dialectical relationship with the approach of habitus, arena, and stock (see figure 1). Habitus is a mental structure that encourages humans to interact and be internalized with the social world, social facts, or traditions [19]. Bourdieu states the form of habitus according to the arena.

Meanwhile, the arena is formed from rules, values, and norms. In this case, the Kethoprak Community consists of people who internalize and believe in the moral values of the Kethoprak Babad Tulungagung as a doxa or norm that must be maintained. Thus, with the background of the cultural arena and the aim of maintaining the existence of that culture, it encourages the formation of habitus to assemble an enculturation strategy through an arena approach, which includes symbolic violence and symbolic domination.

Symbolic violence is carried out to control the younger generation of Tulungagung through disguised socialization in the Kethoprak performance of Babad Tulungagung, for example, the scene that is shown to convey criticism of certain certain certain deviations by the younger generation. The form of criticism is in the form of sarcasm which is conveyed through the player's dialogue. This socialization mechanism is intended to provide the imposition of moral values from the Kethoprak Babad Tulungagung to the younger generation to stay awake in foreign cultural developments. Furthermore, in symbolic dominance, it is manifested in sloganistic and popular language in the dialogue of the Kethoprak performance, such as "Ajining diri ana ing lathi lan budi, dan Becik ketitik ala kethoro". Bourdieu [19] asserts that language is not just a means of communication, but there is an interest behind it [20]. For example, the sentence "becik kedot ala kethoro" means that all bad actions will be revealed one day. The purpose of using this slogan is as a message for the younger generation always to do good. Therefore, humans are not always free to speak.

\section{CONCLUSION}

The dialectical relationship between habitus and arena forms the social capital of the Kethoprak Group in Tulungagung Regency in achieving its goal, namely to re-enculturate the moral values of Kethoprak Babad Tulungagung as the moral guidance of the younger generation in the era of cultural globalization. The potential for moral values is internalized in the community system, forming norms that are focused on the statement that all actions that do not reflect the characteristics of these moral values are considered deviant. Therefore, the steps taken are a socialization strategy in maintaining character: Njawani, Unggahungguh, Adiluhung, Loyalty, and Commitment. They are contained in the moral values of Kethoprak Babad Tulungagung for the younger generation of Tulungagung. 


\section{REFERENCES}

[1] S. Ode, "Budaya Lokal Sebagai Media Resolusi Dan Pengendalian Konflik Di Provinsi Maluku (Kajian,Tantangan Dan Revitalisasi Budaya Pela)," Polit. J. Ilmu Polit., vol. 6, no. 2, pp. 93-100-100, 2016, doi: 10.14710/politika.6.2.2015.93-100.

[2] S. Budhi, "Revitalisasi Kebudayaan dan Tantangan Global," 2020.

[3] R. D. Latuberu and M. Mustika, "Enkulturasi Budaya Pamana," vol. 2, no. 1, pp. 107-113, 2020, doi: 10.38012/jb.v2i1.411.

[4] Koentjaraningrat, Pengantar Antropologi. Jakarta: Rineka, 2012.

[5] S. Soekanto, Sosiologi Suatu Pengantar. Jakarta: PT. Rajawali, 1990.

[6] N. Hendriawan and Y. S. Astuti, "Proses Enkulturasi Sebagai Pendidikan Kecakapan Hidup (Life Skill Education) Pada Masyarakat Kampung Naga Desa Neglasari Kecamatan Salawu Kabupaten Tasikmalaya," J. Siliwangi Seri Pendidik., vol. 3, no. 1, pp. 167-172, 2017.

[7] K. Anwar, "Eksistensi Ketoprak Gaya Baru Siswo Budoyo, Di Tulungagung, Tahun 1958-2002," Avatara, vol. 5, no. 2, pp. 328-342, 2017.

[8] Disbudpar, "Data Kesenian Kabupaten Tulungagung Tahun 2020,” Tulungagung, 2020.

[9] M. B. Miles, A. M. Huberman, and J. Saldaria, Qualitative Data Analysis: A Methode Sourcebook, Edisi 3. United States of America: SAGE Publications, 2014.

[10] S. Sugiyono, Metode Penelitian Kuantitatif, Kualitatif, dan $R \& D$. Bandung: CV Alfabetha, 2017.

[11] S. Sunardi, "Sejarah Kethoprak Siswo Budhoyo." Zulfana, Ayu, \& Fakhrial, Tulungagung, 2021.

[12] B. Bratawijaya, Mengungkap dan Mengenal Budaya Jawa. Jakarta: Pradaya Paramita, 1977.

[13] Y. S. Kristiaji and dan F. Kurwidaria, "Bahan Ajar Bahasa Jawa Di Sma Berbasis Nilai-Nilai Kepribadian Dan Pendidikan Dalam Naskah Ketoprak Rembulan Wungu Karyabondannusantara:Sebuah Studi Psikologi Sastra," Śabdaśāstra, vol. Vol. 2(1), 2018, doi: https://doi.org/10.31004/basicedu.v3i2.34.

[14] B. Widjanarko, "Nilai-nilai Adiluhur Kethoprak Babad Tulungagung." Tulungagung, 2021.

[15] P. Bourdieu, The Forms of Capital. New York:
Greenwood Press, 1986.

[16] N. Angraini, "Pengaruh Kebijakan Perubahan Kurikulum Terhadap Pembelajaran Sekolah,” pp. 3-4, 2019, doi: 10.31227/osf.io/aq2g7.

[17] T. Santoso, Memahami Modal Sosial. 2020.

[18] M. Idrus, "Pendidikan Karakter Pada Keluarga Jawa," Pendidik. Karakter, vol. Vol 2 No I, 2012.

[19] P. Bourdieu, Distinction: A Social Critique of the Judgement of Taste. Cambridge, Massachusetts: Harvard University Press, 1987.

[20] G. Ritzer and D. J. Goodman, Teori Sosiologi Modern, Edisi 6, C. Jakarta: Prenada Media, 2005. 